\title{
Welfare Theories in Family Politics
}

\author{
KRISTÓ Katalin ${ }^{1}$
}

\begin{abstract}
The welfare state is one of the most frequently used social scence terms that causes arguments or political discussions. The role of the state in the development of its social role has changed through time, and parallel with this, the term welfare state has changed too, as well as theories regarding the welfare state. In this study, the author's main goal is to summarise the different theories of the welfare state. Following this, a special approach will be shown in terms of the categorization of the welfare state to show its role in a special welfare: i.e. in what ways does it supports families. This view has not received much attention in detail in the literature so far.
\end{abstract} Keywords: welfare state, family politics, social politics.

The welfare state is one of the most frequently used terms that causes arguments or political discussions. It is a phrase from social science. Many times it is mistakenly thought of as a term connected to a developed economy and high standard of living. Nonetheless, it is also true that states which provide high standards of social welfare do possess these two things. There are many definitions for the welfare state but there is not one exact term that is agreed on in the literature. The welfare state refers to a state that takes responsibility for its citizens' welfare on a given level, for their social safety based on a system of earnings and social services. [1]

The role of the state in the development of its social role has changed through time, and parallel with this, the term welfare state has changed too, as well as regarding the theories of welfare state. In this study, the author's main goal is to summarise the different theories of welfare state. Following this, a special approach will be shown in terms of the categorization of the welfare state to show its role in a special welfare: i.e. in what ways does it support families. This view has not received much attention in details in the literature so far.

Lebeaux and Wilensky started to categorize the role of state according to their role in the welfare system in 1956. They created two groups to differentiate residual and universal welfare states. In the residual state, the social role of the state is reduced to a minimum because it concentrates only on a saftey net for the poor. Opposed to this, the universal or institutional welfare state offers public programmes to many social groups and the main goal of the state is to provide the social welfare services itself. Lebeaux and Wilensky saw these two categories as progress from the residual towards the universal with the latter becoming a dominant one. [2]

In 1980 Korpi had a theory for a marginal and institutional model, but he saw these regimes as able to exist side-by-side, not necessarily one developing into the other. [3]

Chronologically however, the most well-known and one of the first attempts at categorizing is connected to Titmuss, who defined three types of welfare state types in 1958, from which Lebeaux’s and Wilensky’s residual state theory comes from. So, Titmuss' resid-

1 National University of Public Service, Hungary, Budapest, E-mail: kristo.katalin@uni-nke.hu 
ual theory is as described above. The second is the system of "industrial based efficiency", that focuses on social security and appurtenance, so the welfare system has a huge role in this model. Titmuss defines the third model as the "institutional redistributive" welfare state where the state takes responsibility for the goodwill of its citizens. [4]

Following very closely in Titmuss' footsteps is Gosta Esping-Andersen, one of the most frequently quoted typology derives from him, and he also - similarly to Titmuss - differentiated between three different models: the welfare model of the northern states and the liberal and continental welfare model. ${ }^{2}[5]$

Upon creating these models in 1990, Esping-Andersen examines the state's socio-political features and to a lesser extennt the family side, although in his work we can find references to family politics. Because of criticism on his gender-based work, in 1999, he reworked his study and thought of children and women too. He calls our attention to the risks of economic competition and the welfare system if the burdens on the family, but more importantly on women, are not lifted by the state. (In this study, the author looks at the reworked typology.)

In Esping-Andersen's theory, groupings are based on the three pillars of welfare: the role of the state, the family and the market and how spread the programmes and institutions are of the welfare state. Those Northern European countries where the state's social role is very strong are placed in the Northern European group. Prevention is put in focus by this model meaning that the citizen should remain an active part of the labour market as long as possible, but even should he/she fall out or he/she will be eligible for a wide range of social allowances. [6: 235] Esping-Andersen highlights, that the mentioned "activation policy reduces unemployment as well as doubling the positive effects of services given to families: it enables women to have children and to have a career as well to maximise the ratio of the employed.” Esping-Andersen puts Ireland and Great Britain in the "liberal” welfare model, similar to the United States, which supports the solution that the market offers: it urges private welfare service and minimises the responsibility for market setback. In this model, the role of the state is residual and focuses on those in need and is restricted to services for the “registered" poor citizens. Benefits are linked to being active in work which does not help the unemployed, and to get these rights women with small children need cheap institutions to take care of their children.

According to Esping-Andersen, in most of the countries in Europe the classic family welfare responsibities are typical. This family-concentrated feeling is strengthened even more by the dominance of social insurance. In this model, the most important thing is the safety of the main (usually male) breadwinner's role.

The "family's exceptional welfare role can yield against risks of social exclusion but at the same time it has a negative effect on women's endeavours for economic independence. It can be shown, that the most important factor of the family-based welfare-system is the low birth rate." [7]

Nowadays however the categories set up by Esping-Andersen cannot be taken as a generally used model since less and fewer countries can be categorised into one type. Still, this

2 Gosta Esping-Andersen in his work entitled The Three Worlds of Welfare Capitalism, published in 1990 described the three types of welfare states as corporate, social democrat and liberal. He uses the categories quoted by us in his developed work, entitled Social Foundations of Postindustrial Economies and published in 1999. Later, because of criticism about his work, he supplemented these categories with two more, the Mediterranean and East-Asian model. 
model is perfect for showing that welfare services can be categorised into a system and therefore give us some idea of the sociopolicy of the given country.

Although Esping-Andersen's model is still one of the most frequently quoted typology, it has been criticised many times from different directions. In 1991, Castles and Mitchell defined a fourth type to go with Esping-Andersen's three existing ones, naming New Zealand, Australia and Great Britain, and named these a radical welfare system. According to these authors, state division is only true for the poorest and people most in need as well as stating that the states in this group have the lowest welfare spending, but with equal salary. [8]

Leibfried in 1992 examined the welfare states along two main lines: the development of the social citizens and the success of the system in its fight against poverty along a dimension. Leibfried also found the solution in a fourth type which in the early stages he called an elementary welfare regime, and put the South European welfare systems in this group. [9]

In 1996 Ferrera also developed a system of four grades with the names of Anglo-Saxon, Bismarck, Scandinavian and South European. [10]

Korpi and Palme had five types by 1998 and defined these categories as independent state financed, corporate with basic safety. [11]

Most of the criticism relating to Esping-Andersen relates to gender and these are the criticisms with the help of which we gradually get to the attempts to categorize the welfare states of family politics. The absence of gender roles was heavily criticised by Lewis, Ostner, Orloff, Siaroff and Sainsbury.

Jane Lewis and Ilona Ostner differentiated the welfare states based on how well they are built on the classical man and woman role dichotomy, more specifically, the man as the breadwinner and the woman as the carer. The classical "male breadwinner model's” features are the following:

- the man's salary is enough to satisfy the family's needs;

- both parties' social rights are connected to the man;

- typically it is the man who gets the financial benefits from the state;

- the state does not take the burden of taking care of the dependent family members responsibility from the woman. [12]

Orloff in his work in 1993 defines the theory of Esping-Andersen as having categories that reflect the standards of men; however a welfare state means different things to men and women as well. When speaking of women, one should speak of the access to work and the opportunities of an independent household in connection to the analyzing of welfare state's effects. [13]

Siaroff in 1994 - also based on a gender based approach - in addition to the three classical types speaks of a fourth one as well, that is about the late mobilization of women, and can be seen in Mediterranean and Asian countries. [14]

The Lewis-Ostner line of thought was developed further by Sainsbury who pointed out that the male-breadwinner model is one dimensional and is not able to tell a difference between the welfare regimes. Sainsbury defines two models: as opposed to the male-breadwinner model she defined an individual model in which the man and wife share the family's financial needs and the nurturing of the child as well. [15]

Later Sainsbury talks about the two-earner-model, emphasising the role of the state in the employment of women. [16] 
Lewis' research later focused on home care. This work by women could mean taking care of children, volunteer work in a civil organisation, taking care of the elderly or a disabled relative but also includes taking care of ("whole” men) other family members. Whether to pay women for this work or for the government to organize this work in an institution is a fertile ground for arguments to this day, as the latter would enable women to be available on the labour market. [17]

In the centre of Korpi's typology is the equality of chances between nations. In the two dimensional model the family policies are differentiated based on whether they support the traditional or two-earner model. So we can see that Korpi has modelled his categories based on Lewis' one dimensional, male-earner model and on Sainsbury's later, two-earner model. Based on this, the author differentiates three family policy regimes. He lists among the supporters of the classical family model France, Austria, Germany and Belgium. Among the two-breadwinner nations he puts Denmark, Sweden, Norway and Finland. Finally, he identifies Australia, Great Britain, New Zealand, Canada, the United States of America and Japan as liberal, market-oriented states that implement family politics. [18]

Haas was the next person who developed further Lewis' theory of home care with his system of parental leave and women's labour market, grouping the nations of the European Union's 15 existing states of the time. Haas differentiates between four types: privatized, family oriented, market oriented and intensive model. In the privatized, or in other words non-interfering model, nurturing is a women's role and work is a man's role and thus very much divided. The Southern European countries grouped in this model allowed parental leaves only in 1998 in a limited number because of European Union recommendations. In these countries, the employment rate of women is very low and the rate of unemployment among them is double that of men. In the family oriented model fertility is in the centre, the employment of women is average but the institution of parental leave exists (typically three years with few perks). Austria, Germany, Belgium, Luxemburg and France are in this group. For countries in the market oriented group parental leave did not exist before the European Union introduced it and the state does not support institutional child care. In spite of this, the employment of women is quite high, especially among part-timers. This can be best seen in Great Britain, Ireland and the Netherlands. In the Scandinavian countries, equality both in the job market and in care is given to both parents. To enable this, a high standard of institutional childcare ensures freedom for the parent as well as childcare leave for both parents (with a high substitution ratio). [19]

Wall's model has a similar logic to Haas' parental leave system. This model typifies the institutions based on three main aspects in order to resolve the dilemma of the family and work. The first is the division of paid and unpaid work within the family, the second is the design of motherhood as a social aspect and the third is the cultural dimension between the working parent and the welfare state. Based on the above, he sets apart six types by analyzing nineteen European countries. The first type is characterized by a one-year parental leave (Sweden, Denmark, Iceland), the second is the group of countries that support parental choice (Finland, France, Belgium), the third is home care focused (Germany, Hungary, Czech Republic), the fourth model is characterized by short parental leave and part-time work (The Netherlands, Great Britain), and in the fifth category the emphasis is on a short leave and the male's role as breadwinner (Italy), and finally, the sixth model supports the return to full-time work (Portugal). [20] 
The improvement of the theory of "familism" is by Leitner, ${ }^{3}$ and it marks the welfare regimes according to how the state solves the care of the child, the elderly and the handicapped within the state - market - family triangle. (Familism is defined as a social structure where the needs of the family are more important and take precedence over the needs of any of the family members.) Leitner separates four models. In the first model, explicit familism, the state acknowledges only the responsibility of the family in the carer's role and encourages care at home with no alternatives. The second type is optimal familism which also promotes home care but in this model there is room for alternative solutions too. In the third category, implicit familism, the state does not support the families in how they care for their loved ones and does not provide any alternatives. The fourth model's main aim is defamilarization, where the state creates services where the burden is taken off the family's shoulders and resolves the issues by creating institutions to care for those who are not able to care for themselves. [21]

Bettio and Plantenga created five categories with care in the centre of attention but also focusing on children's and elderly people's care. In the first group we can find the countries where the state shifts every task to the family, especially the women. As a result of this, the state prefers pecuniary care to services, and this shuffle favours the elderly opposed to small children. Typically South European countries belong in this group (except Portugal). For countries in the second group home care, or in other words informal care, is also very important however these children have a chance of services given to them by the private sector whereas for the elderly it is this state that provides the services. According to the duo, this is true for Great Britain and the Netherlands. The third cluster consists of Austria and Germany, where the care of the children is left to the family but they are supported by the state in financial terms. Belgium and France are in the fourth group where the state is providing more and more institutional support for both children and the elderly. In the last group are the Scandinavian countries where the institutionalised care for children and the elderly is universally available and the role of the family as caretaker is minimal. [22]

Thévenon classified the countries into five groups during his work examining the OECD (Organisation for Economic Cooperation and Development) countries in 2011. Scandinavian countries belong in the first group where continuous and high level of care is provided for parents raising children under the age of three (Denmark, Finland, Iceland, Norway, and Sweden). France, Germany, Luxembourg and Belgium belong in the second group where the financial support is typical but the model of two breadwinners is less popular. Anglo-Saxon countries give less natural allocation to working parents with young children, but instead high financial support is available to families raising pre-school children.

Countries in the fourth group have the chance to get paid leave in a very limited sense and the childcare opportunities are not so wide spread. According to the theory, south European countries belong here along with Japan and Korea. Eastern European countries are in the fifth group where typically the means-tested services are in the limelight while less emphasis has been placed on policies enabling women to combine motherhood with paid work. According to Thévenon Hungary stands out from this group because it offers a wider range of support to families with small children, the maternity leave is the longest here and financial support is generous as well (although according to the author, the poorest families get the least of this). [23]

3 Leitner starts off from Kammermann and Kahn's two element theory that differentiates between explicit and implicit family politics. 
A very common criticism of theories of welfare states and models of family policies are that every such grouping is static since these models are not able to handle systematic changes in time. This static state is resolved by Pfau-Effinger's model of 2010 which separates three different types. The family politics in the first category are based on the man as the breadwinner with the state providing wide-spread support during childhood ages 3-6, but the allowance for children under the age of 3 is much slimmer. In this group parental leave is limited with no extra paternal leave for the father. In the second model equality for women is ensured by a wide-spread childcare system. In this type, universal childcare is available to the parents, yet parental leave is not so common and thus it not a necessity for fathers. The third type is quite flexible as it allows several options for parents with young children and the family policy practice of gender divisions. The differences between these theories are the fact of paternal leave which does not exist in the first case. Pfau-Effinger investigates the Finnish, German and Spanish states' political history, the changes in tools and categorizes based on the change in goals. [24]

By looking through the welfare states and their family policies we can see that each author has his own typology even if it differs in only some small detail, like the name of the regime or the groupings of the countries. ${ }^{4}$ The models of family policies concentrate on the two questions of the classical family model or the the two-earner-model. From this, we can conclude, that the most important question in the literature on family politics is the role of the woman, the mother, how this role changes and in what way it influences the rethinking of the instititutions. As a result we see how important it is to be able to choose between the different services. Therefore over the years, the importance of choice has become more and more important, whereas in the past it got hardly any attention at all.

Makay and Blaskó also draw our attention to this very fact. "Over the last years more EU members have modified their system regarding financial support for parents with young children. The main direction of the latest modifications is regulations relating to having a choice of financial support. In the background is the idea that by providing flexibility to mothers they will be able to harmonise work and motherhood.” According to the authors, every family support theory can be considered flexible that gives a chance to the parent (in particular to mothers) to be able to decided how much time they would like to spend at home with their child and in what way they would like to achieve this as well as when and how they would like to go back to work. [25: 50] In other words, the family support system enables the free choice for the parent to finally not have to choose between work and the family and the state support will accommodate the family's choice. The authors agree that the flexible or partly flexible system of financial child support works well in many European Union countries, the most flexible considered to be in Belgium, the Czech Republic and France.

The Hungarian family support system is considered rather rigid, but an important flexible feature of this system is that fathers can also apply for the support. Another advantage is that from 1 January 2014 the so called Child Support Extra means that should the parent return to his or her workplace a year after of the child's birth, the original financial support will still be available for the full period. This still does not make the Hungarian system flexible, but it is a big step forward in order to achieve it.

4 Not to mention the latest research in connection with the welfare states which concentrate on how globalization effects the typology of the welfare states, or the coordinated mechanism of the European Union's social security systems or spontaneous harmonization. 


\section{References}

[1] TOMKA B.: A jóléti állam Európában és Magyarországon. Budapest: Corvina, 2008.

[2] WILENSKY, H. L., LEBEAUX, Ch. N.: Industrial Society and Social Welfare: the Impact of Industrialization on the Supply and Organization of Social Welfare Services in the United States. New York: Free Press, 1965.

[3] KORPI, W.: Approaches to the Study of Poverty in the United States. Critical Notes from a European Perspective. In. COVELLO, V. T. (Ed.), Poverty and Public Policy. Rochester: Schenkman Books Inc., 1980.

[4] TITMUSS, R. M.: Essays on 'The Welfare State. Sydney: George Allen \& Unwin, 1958.

[5] ARTNER A.: Az európai jóléti modellek és fenntarthatóságuk. Múhelytanulmányok, 89 (2011), 1-18.

[6] HOFFMAN I.: Szociális igazgatás. In. LAPSÁNSZKY A. (Ed.), Közigazgatási jog. Fejezetek szakigazgatásaink köréből III. Humán közszolgáltatások igazgatása. Budapest: Complex Kiadó Jogi és Üzleti Tartalomszolgáltató Kft., 2013.

[7] ESPING-ANDERSEN, G.: Ismét a Jó Társadalom felé? Esély, 6 (2006), 15-18.

[8] CASTLES, F. G., MITCHELL, D.: Three worlds of welfare capitalism or four? Public Policy Program. Australian National University, Discussion Paper, 21 (1991), 1-30.

[9] LEIBFRIED, S.: Towards a European Welfare State? On Integrating Poverty Regimes into the European Community. In. FERGE Zs., KOLBERG J. E. (Eds.), Social Policy in a Changing Europe. Vienna: European Centre for Social Welfare Policy and Research, Campus Verlag/Westview Press. 1992.

[10] FERRERA, M.: The Southern Model of Welfare in Social Europe. Journal of European Social Policy, 1 (1996), 17-37. DOI: https://doi.org/10.1177/095892879600600102

[11] KORPI, W., PALME, J.: The Paradox of Redistribution and Strategies of Equality: Welfare State Institutions, Inequality, and Poverty in the Western Countries. American Sociological Review, 5 (1998), 661-687. DOI: https://doi.org/10.2307/2657333

[12] LEWIS, J., OSTNER, I.: Gender and the Evolution of European Social Policies. Emergent Supranational Social Policy: The EC's Social Dimension in Comparative Perspective. Cambridge: Harvard University, Center for European Studies, 1991.; SZIKRA D.: Családtámogatások Európában történeti perspektívában. In. SIMONYI Á. (Ed.), Családpolitikák változóban. Budapest: Szociálpolitikai és Munkaügyi Intézet, 2010.; GYARMATI A.: A családtól az egyénig - A családdal kapcsolatos globális változások okai és intézményi következményei. In. RÁCZ A. (Ed.), Modernizációs kihívások és szolgáltatási válaszok a gyermekvállalás- és nevelés területén. Budapest: Rubeus Egyesület, 2013.

[13] ORLOFF, A. S.: Gender and the Social Rights of Citizenship: The Comparative Analysis of Gender Relations and Welfare States. American Sociological Review, 3 (1993), 303-328.; GYARMATI A., 2013., 17. DOI: https://doi.org/10.2307/2095903

[14] SIAROFF, A.: Work, Welfare ang Gender Equality: A New Typology. In. SAINSBURY, D. (Ed.), Gendering Welfare States. New York: SAGE Publications Ltd., 1994.

[15] SAINSBURY, D.: Women's and Men's Social Rights: Gendering Dimensions of Welfare States. In. SAINSBURY, D. (Ed.), Gendering Welfare States. New York: SAGE Publications Ltd., 1994. 
[16] SAINSBURY, D.: Gender, equality, and welfare states. Cambridge: Cambridge University Press, 1996.

[17] LEWIS, J.: Gender and Welfare Regimes. In. LEWIS, G., GERWITZ, S., CLARKE, J. (Eds.), Rethinking Social Policy. New York: SAGE Publications Ltd., 2000.

[18] KORPI, W.: Faces of Inequality: Gender, Class and Patterns of Inequalities in Different Types of Welfare States. Social Politics, 2 (2000), 127-191.DOI: https://doi.org/10.1093/sp/7.2.127

[19] HAAS, L.: Parental Leave and Gender Equality: Lessons from the European Union. Review of Policy Research, 1 (2003), 89-114.; GYARMATI A., 2013., 19.https://doi.org/10.1111/1541-1338.d01-6

[20] WALL, K.: Main Patterns in Attitudes to the Articulation between Work and Family Life: a Cross-National Analysis. In. LYONETTE, C., LEWIS, S., CROMPTON, R. (Eds.), Women, Men, Work and Family in Europe. New York: Palgrave Macmillan, 2007.

[21] LEITNER, S.: Varieties of Familialism. The caring function of the family in comparative perspective. European Societies, 4 (2003), 353-375.; GYARMATI A., 2013., 20.; SZIKRA D., 2010., 13-14. DOI: https://doi.org/10.1080/1461669032000127642

[22] BETTIO, F., PLANTENGA, J.: Comparing care regimes in Europe. Feminist Economics, 1 (2004), 85-113.; GYARMATI A., 2013., 20-21. https://doi.org/10.1080/1354570042000198245

[23] THÉVENON, O.: Family Policies in OECD Countries: A Comparative Analysis in Developed Countries. Population and Development Review, 1 (2011), 57-87.

[24] PFAU-EFFINGER, B.: Comparing path dependence and path departure in family policy development - the example of Germany and Finland. ESPAnet Annual Conference, 2011.; GYARMATI A., 2013., 21-22.

[25] MAKAY Zs., BLASKÓ Zs.: Családtámogatás, gyermeknevelés, munkavállalás. In. ŐRI P., SPÉDER Zs. (Eds.), Demográfiai Portré 2012. Jelentés a magyar népesség helyzetéről. Budapest: KSH Népességtudományi Kutatóintézet, 2012. 